
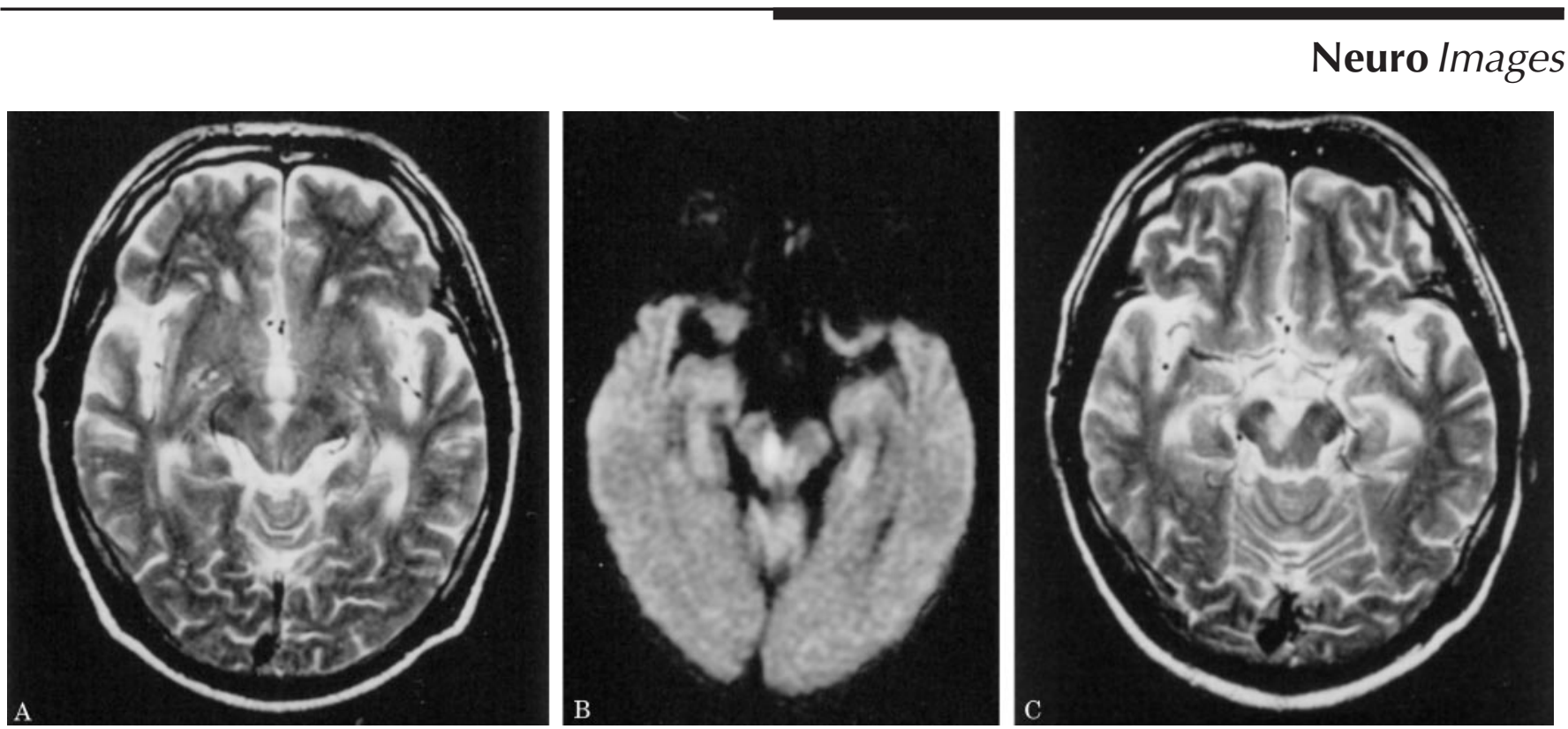

Figure. (A) T2-weighted MR image performed 6 hours after the onset of symptoms demonstrates a subtle hyperintensity area in the midbrain. (B) Diffusion-weighted MR image performed at the same time clearly demonstrates a hyperintensity area around the superior cerebellar peduncle just below and medial to the red nucleus. (C) T2-weighted MR image performed 4 days after the onset demonstrates a hyperintensity in the corresponding area.

\section{MRI of Claude's syndrome}

Hiroyuki Asakawa, MD, Kiyoyuki Yanaka, MD, PhD, Tadao Nose, MD, PhD, Ibaraki, Japan

A 74-year-old man presented with sudden onset of right oculomotor palsy with sparing of the pupil and marked ataxia of the left upper limb. In 1912, the French neurologist Henri Claude first described the syndrome of ipsilateral oculomotor nerve palsy with

Address correspondence and reprint requests to Dr. Kiyoyuki Yanaka, Department of Neurosurgery, Institute of Clinical medicine, University of Tsukuba Tsukuba, Ibaraki 305-8575, Japan; e-mail: kyanaka@md.tsukuba.ac.jp contralateral asynergia that bears his name. ${ }^{1}$ Claude syndrome is caused by a lesion of the ventromedial midbrain, resulting in the combination of an ipsilateral oculomotor palsy and contralateral ataxia. There have been few studies describing the MR appearance of lesions associated with this syndrome. ${ }^{2}$ MR imaging clearly localized the lesion of Claude syndrome in this case (figure).

1. Claude H. Syndrome pedonculaire de la region du noyau rouge. Rev Neurol (Paris) 1912;23:311-313.

2. Broadley SA, Taylor J, Waddy HM, Thompson PD. The clinical and MRI correlate of ischaemia in the ventromedial midbrain: Claude's syndrome. J Neurol 2001;248:1087-1089. 


\title{
Neurology
}

\author{
MRI of Claude's syndrome \\ Hiroyuki Asakawa, Kiyoyuki Yanaka and Tadao Nose \\ Neurology 2003;61;575 \\ DOI 10.1212/WNL.61.4.575
}

This information is current as of August 25, 2003

\section{Updated Information \& Services}

References

Subspecialty Collections

Permissions \& Licensing

Reprints including high resolution figures, can be found at: http://n.neurology.org/content/61/4/575.full

This article cites 2 articles, 0 of which you can access for free at: http://n.neurology.org/content/61/4/575.full\#ref-list-1

This article, along with others on similar topics, appears in the following collection(s):

fMRI

http://n.neurology.org/cgi/collection/fmri

Infarction

http://n.neurology.org/cgi/collection/infarction

MRI

http://n.neurology.org/cgi/collection/mri

Information about reproducing this article in parts (figures,tables) or in its entirety can be found online at:

http://www.neurology.org/about/about_the_journal\#permissions

Information about ordering reprints can be found online:

http://n.neurology.org/subscribers/advertise

Neurology ${ }^{\circledR}$ is the official journal of the American Academy of Neurology. Published continuously since 1951, it is now a weekly with 48 issues per year. Copyright . All rights reserved. Print ISSN: 0028-3878. Online ISSN: 1526-632X.

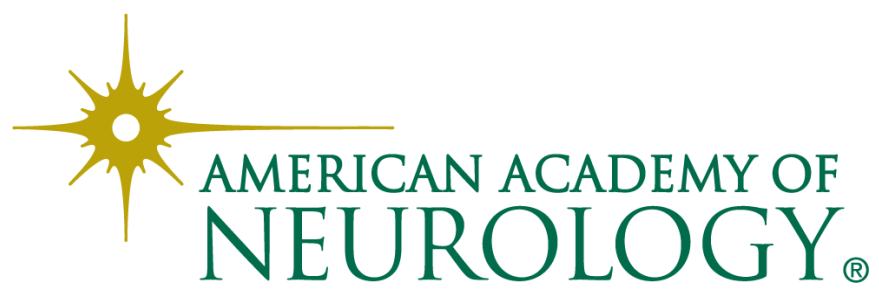

